\title{
Determination of the Safe Duration of Benzene Non-Carcinogenic Exposure in Motor Workshop Area
}

\author{
Ramdhoni Zuhro ${ }^{1}$, Abdul Rohim Tualeka ${ }^{1}$, Ratna Ayu Harsetianingrum ${ }^{1}$ \\ ${ }^{1}$ Department of Occupatioanl Health and Safety, Public Health Faculty, Airlangga University, Surabaya
}

\begin{abstract}
Workers in motor workshop area who working more than 3 years were at risk of exposure to benzene from improved emissions of vehicles in their work environment. The objectives of this study were to measure the duration of safe exposure to benzene in the work environment of motor workshops and to know Risk Quotient (RQ) due to exposure to benzene (non-carcinogenic).

This type of research was an analytical study by using Environmental Health Risk Analysis design, which was used to assess and predict what would happen due to hazardous substances exposure. In this case, benzene was used as one component in fuel oil. The sample population was 15 people from all workers in a motor workshop area in Surabaya. Data analysis was using manual data calculation to know the benzene intake, the Risk Quotient (RQ) on worker and the duration of safe exposure of benzene in motor vehicle workshop area.

It was found that the average intake of benzene in motor workshop area in Surabaya was $0.01631 \mathrm{mg} / \mathrm{kg} /$ day, the average of RQ was was $1.91882 \mathrm{mg} / \mathrm{Kg} /$ day or RQ $>1$, indicating that workers in motor workshop area had health risk due to benzene exposure) and the safe duration of benzene exposure for workers in the motor workshop area was 5.43 years. Therefore, it was necessary to control the work environment to reduce effect of the benzene exposure on workers. It was concluded that workers in the motor workshop area were at a risk of benzene exposure but could work safely for 5.43 years. It was depend on the food intake and the condition of each body of workers in the motor workshop environment. Recommendations were by consuming CYP2E1 enzyme contained in cow liver and salmon to lower benzene levels in the body. ${ }^{8}$
\end{abstract}

Keywords: Benzene, Risk Quotient, Safe Duration, Workers, Motor Workshop

\section{INTRODUCTION}

Everyone can be exposed to small amounts of benzene every day. Benzene exposure can occur in workplace, outside environment or at home. The main sources of benzene are cigarette smoke, motor vehicle emissions and emissions of industrial activities. Motor vehicle emissions produce Benzene, Toluene and Xylene (BTX) which are carcinogenic chemicals. One of the places that has a lot of motor vehicle emissions is motor workshop area. Workers in motor workshop area who working more than 3 years were at risk of exposure to benzene from improved emissions of motor vehicles in their work environment.

BTX is a Volatile Organic Compound (VOC), a carbon-containing compound that has a high vapor pressure at room temperature. The most commonly known VOCs are solvents, and other VOCs are widely used such as monomers and fragrances. ${ }^{12}$ BTX is a chemical classified as toxic to health, whether carcinogenic and increases oxidative stress. ${ }^{2,3,9,14}$ Besides BTX non-carcinogenic can affect the hematopoietic system, central nervous system and reproductive system. The toxic nature of BTX in high-level exposure leads to neurotoxic symptoms. Continuous exposure in high levels of BTX can affect damage to the human bone marrow, DNA in mammalian cells and immune system. Light exposure of BTX causes irregular heartbeats, headaches, dizziness, nausea and even fainting if the exposure continued for a long time. Early manifestations of its toxicity are anemia, leukocytopenia, and thrombocytopenia. ${ }^{11}$ 
Benzene as one member of BTX is a compound that is non polar because it does not have a pair of free electrons. The chemical structure of benzene has 3 double bonds. The existence of double bonds on benzene makes this compound harmful to humans and other living things because it is carcinogenic. Benzene is non polar compund that insoluble in water, but soluble in organic solvents such as diethyl ether, carbon tetrchloride or hexane. ${ }^{1}$ Benzene is an aromatic hydrocarbon compound having an enclosed carbon chain with 6 hydrogen atoms having unsaturated properties with $\mathrm{C} 6 \mathrm{H} 6$ chemical formula.

Several agencies in the field of health and safety such as WHO (World Health Organization), and the Agency for Toxic Substances and Disease Registry (ATSDR) have determined that Benzene is a substance that can cause cancer. In addition, acute effects can be eye irritation, respiratory tract, dizziness and loss of consciousness. ${ }^{1}$ The Indonesian government through the labor department has categorized Benzene as carcinogenic according to Permenakertrans No.13/ $\mathrm{MEN} / \mathrm{X} / 2011$ in $2011 .^{7}$

The results of Haen and Oginawati ${ }^{4}$ showed that there is a significant relationship between benzene concentration in breathing zone with hemoglobin, erythrocytes and also eosinophils. It could be related to bone marrow, because the formation of blood cells occurs in the bone marrow. Robbins and Kumar said that benzene can cause myeloid stem cell failure resulting in reduced production of hemoglobin and red blood cells. If red blood cell deficiency occurs for a long time, it can cause aplasti anemia. ${ }^{10} \mathrm{~A}$ study conducted by Lan et al in 2004 concluded that in benzene-exposed workers with relatively low concentrations $(<1 \mathrm{ppm})$ there was a haematological effect. In the study also found that benzene exposure also has a significant relationship with eosinophils. The number of abnormal eosinophils is one of the hematopoetic disorders that can cause eosinophilia. Eosinophilia is a response to a disease. If a foreign material enters the body it will be detected by lymphocytes and neutrophils, which will release the material to attract the eosinophils to the area. Then eosinophils will release substances that can kill parasites and also destroy abnormal cells.

Based on the research previously about benzene in work environment, those have not been conducted research about safe duration (Dt Safe) for workers to work safely in work environment that has benzene exposure yet. Motor workshop area as the work environment that has benzene exposure, the workers and the owner of motor workshop have safe duration for wokers to work safely in motor workshop area. This is done to prevent health problems (non-carcinogen) caused by benzene exposure.

Therefore, based on the explanation above, we would like to measure the safe duration of benzene (non-carcinogen) in motor workshop area and to know workers characteristic, concentration of benzene exposure, respiration rate, intake and Risk Quotient (RQ) of benzene exposure (non-carcinogen).

\section{MATERIAL AND METHOD}

This type of research was an analytical study by using Environmental Health Risk Analysis design, which was used to assess and predict what would happen due to hazardous substances exposure. In this case, benzene was used as one component in fuel oil.

The design of study started from collecting secondary data that related to the work process which included the concentration of benzene in the air and the number of operators involved. Moreover, the study conducted primary data collection that associated with operators weight, exposure time, exposure frequency and exposure duration of benzene chemicals.

The sample population was 15 people from all workers in a motor workshop area in Surabaya with age between 19 years until 46 years and work period from 7 months until 20 years. Data analysis was using manual data calculation to know the benzene intake, the Risk Quotient (RQ) on worker and the duration of safe exposure of benzene in motor vehicle workshop area. Measurements of Benzene concentrations in the work environment were carried out using Minipump and Carcoal sample media. The reference used was NIOSH 1501 sampling and analysis.

The data was obtained through primary data by filling out questionnaires about age, weight and working period. Data of complete blood examination on respondents and benzene exposure in the workplace assisted by experts which is nurses from UPTK3 Hiperkes in East Java, Indonesia.

The variables studied were workers characteristics (age, weight and working period), concentration 
of benzene exposure, respiration rate, intake, Risk Quotient (RQ) and safe duration (Dt Safe) of benzene exposure (non-carcinogenic) in motor workshop area. Data analysis in this study was conducted by using quantitative data analysis to determine the concentration of safe exposure of Benzene to workers.

\section{FINDINGS}

\section{A) Workers Characteristics}

The workers characteristics in this study included age, weight and working period of 15 worker respondents in motor workshop area. Based on Table 1. in weight distribution, it was known that the most weight group of workers was group 54-62 $\mathrm{Kg}$ as much as 6 respondents (40,0\%), while the highest weight of 78 $\mathrm{Kg}$ and the lowest weight of $45 \mathrm{Kg}$. In age distribution, it was known that the largest group of workers was aged between 19 years to 25 years as many as 7 respondents $(46,7 \%)$, and groups of workers with age between 40 to 46 years was at least 2 respondents (13.3\%). In working period distribution, the working period of the worker respondents was categorized into two that was the working period less than 3 years and the working period more than 3 years. It was known that the largest group of workers had working period more that 3 years in motor workshop area as much as 9 respondents $(60,0 \%)$.

Table 1. Distribution of Workers Characteristics in Motor Workshop Area

\begin{tabular}{|c|c|c|c|}
\hline \multicolumn{2}{|c|}{ Workers Characteristic } & \multirow{2}{*}{$\frac{N}{5}$} & \multirow{2}{*}{$\frac{\%}{33.3}$} \\
\hline 1. Weight & $45-53$ & & \\
\hline & $54-62$ & 6 & 40.0 \\
\hline & $63-71$ & 3 & 20.0 \\
\hline & $72-80$ & 1 & 6.7 \\
\hline & Total & 15 & 100.0 \\
\hline \multirow{4}{*}{$\begin{array}{ll}\text { 2. } & \text { Age } \\
& \text { (Years Old) }\end{array}$} & $19-25$ & 7 & 46.7 \\
\hline & $26-32$ & 3 & 20.0 \\
\hline & $33-39$ & 3 & 20.0 \\
\hline & $40-46$ & 2 & 13.3 \\
\hline \multicolumn{2}{|r|}{ Total } & 15 & 100.0 \\
\hline \multirow{2}{*}{$\begin{array}{l}\text { 3. Working Peri- } \\
\text { od (Years) }\end{array}$} & $<3$ & 6 & 40.0 \\
\hline & $\geq 3$ & 9 & 60.0 \\
\hline \multicolumn{2}{|r|}{ Total } & 15 & 100,0 \\
\hline
\end{tabular}

\section{B) Concentration of Benzene Exposure}

Based on the measurement of benzene concentration in Table 2., the result of concentration of exposure centered on reparation section of motor workshop with benzene level concentration was $0,3974 \mathrm{ppm}$.

Table 2: Measurement of Concentration of Benzene Exposure in Motor Workshop Area

\begin{tabular}{|l|c|}
\hline \multicolumn{1}{|c|}{ Measurement Location } & Benzene Level (ppm) \\
\hline $\begin{array}{l}\text { Reparation Section of Motor Work- } \\
\text { shop }\end{array}$ & 0.3974 \\
\hline $\begin{array}{l}\text { Administration Section of Motor } \\
\text { Workshop }\end{array}$ & - \\
\hline
\end{tabular}

Based on the measurement results by Balai Hiperkes Surabaya, the concentration of benzene in the motor workshop area was 0.3974 ppm or 1.267 $\mathrm{mg} / \mathrm{m}^{3}$. The Concentration of Benzene was above the Minimum Risk Level (MRL), level of benzene inhaled exposure assigned by $\mathrm{ATSDR}^{1}$, for acute exposure $(\leq 14$ days $)=0.009 \mathrm{ppm}$, moderate exposure (15-364 days $)=0.006 \mathrm{ppm}$, and chronic exposure $(\geq 365$ days $)$ $=0.003 \mathrm{ppm}$. The concentration of benzene based on TLV value specified in Peraturan Menteri Tenaga Kerja dan Transmigrasi Nomor Per.13/MEN/X/2011 in 2011 about Threshold Limit Value (TLV) of physical factors and chemical factors in workplace, it was still below the $\operatorname{TLV}\left(1.59 \mathrm{mg} / \mathrm{m}^{3}\right){ }^{7}$

\section{C) Respiration Rate}

Based on the calculation of the respiration rate on the worker respondents, the highest respiration rate of workers was $0.69 \mathrm{~m}^{3} /$ hour, the lowest respiration rate of worker respondents was $0.55 \mathrm{~m}^{3} /$ hour and the average respiration rate of worker respondents was $0.61 \mathrm{~m}^{3} /$ hour.

\section{D) Intake}

The formula used to determine the intake of benzene toxin in the body is:

Intake Benzene Non - Carcinogen $=\frac{\mathrm{C} \times \mathrm{R} \times \mathrm{tE} \times \mathrm{fE} \times \mathrm{Dt}}{\mathrm{Wb} \times \mathrm{Tavg}}$

Notes:

$\mathrm{C}=$ Benzene Concentration $\left(\mathrm{mg} / \mathrm{m}^{3}\right)$

$\mathrm{R}=$ Respiration Rate $\left(\mathrm{m}^{3} /\right.$ hour $)$

$\mathrm{t}_{\mathrm{E}} \quad=$ Time of exposure (hour/day) 
$\mathrm{f}_{\mathrm{E}}=$ Frequency or Average exposure in year (day/year)

Dt $=$ Duration of Exposure (year)

$\mathrm{W}_{\mathrm{b}}=$ Weight $(\mathrm{Kg})$

$\mathrm{T}_{\text {avg }}=$ Average Exposure of Benzene (noncarcinogen)

30 years x 365 day/year

Table 3. Intake, Risk Quotient (RQ) and Safe Duration (Dt Safe) of Benzene Exposure (NonCarcinogenic) in Motor Workshop Area

\begin{tabular}{|c|c|c|c|}
\hline $\begin{array}{c}\text { Respon- } \\
\text { dents }\end{array}$ & $\begin{array}{c}\text { Benzene } \\
\text { Intake (mg/ } \\
\text { Kg/day) }\end{array}$ & $\begin{array}{c}\text { Risk Quotient } \\
\text { (RQ) } \\
\text { (mg/Kg/day) }\end{array}$ & $\begin{array}{c}\text { Safe Dura- } \\
\text { tion } \\
\text { (Years) }\end{array}$ \\
\hline 1 & 0.00807 & 0.94941 & 5.43 \\
\hline 2 & 0.00797 & 0.93764 & 5.43 \\
\hline 3 & 0.04197 & 4.93764 & 5.43 \\
\hline 4 & 0.00148 & 0.17411 & 5.43 \\
\hline 5 & 0.00175 & 0.20588 & 5.43 \\
\hline 6 & 0.00920 & 1.08235 & 5.43 \\
\hline 7 & 0.01238 & 1.45647 & 5.43 \\
\hline 8 & 0.03319 & 3.90470 & 5.43 \\
\hline 9 & 0.00760 & 0.89411 & 5.43 \\
\hline 10 & 0.00960 & 1.12941 & 5.43 \\
\hline 11 & 0.00269 & 0.31647 & 5.43 \\
\hline 12 & 0.01050 & 1.23529 & 5.43 \\
\hline 13 & 0.02169 & 2.55176 & 5.43 \\
\hline 14 & 0.04798 & 5.64470 & 5.43 \\
\hline 15 & 0.02867 & 3.37294 & 5.43 \\
\hline Average & 0.01631 & 1.91882 & 5.43 \\
\hline
\end{tabular}

It was known that the exposure concentration (C) was $1,267 \mathrm{mg} / \mathrm{m}^{3}$, the frequency or average exposure $\left(f_{E}\right)$ of Benzene was 288 days/year and the average exposure of benzene (non-carcinogenic) $\left(\mathrm{T}_{\mathrm{avg}}\right)$ was $30 \times 288$ days. Table 3 below describes the results of Intake Benzene calculations on workers, Risk Quotient (RQ) and Safe Duratin (Dt Safe) in the work environment. It was known that the maximum intake received by the worker is $0.04798 \mathrm{mg} / \mathrm{Kg} /$ day.

The intake value is directly proportional to the chemical concentration value, the frequency of exposure, and the duration of exposure, which can be interpreted the greater the value the greater the intake of a person. Intake is inversely proportional to the weight value, ie the greater the weight the smaller the health risk.

\section{E) Risk Quotient (RQ)}

The formula used to calculate the RQ is:

$$
\text { Risk Quotient }(R Q)=\frac{\text { Intake }}{R f C}
$$

The risk characteristics are intended to determine whether a toxin exposure has a risk or not to the human body. Risk Quotient (RQ) is the result of comparison between the value of Intake with reference dose of a Reference of Concentrate (RfC) exposure. The RfC value for benzene based on US-EPA was $0,0085 \mathrm{mg} / \mathrm{Kg}$ / day. ${ }^{13}$ Based on the calculation data in Table 3., it was known that the RQ in the average worker was 1.91882 $\mathrm{mg} / \mathrm{Kg} /$ day and the highest RQ was $5.64470 \mathrm{mg} / \mathrm{Kg} /$ day. This showed that the exposure of benzene to workers motor workshop area had a risk of health problems. Based on the data distribution, there were 9 worker respondents with high risk of health disorder $(\mathrm{RQ}>1)$ and 6 worker respondents with $\mathrm{RQ}<1$. This was known that most of workers have potential health problems from non-carcinogenic effects of benzene exposure in motor workshop area.

There is actually no value for the lowest safe limits on exposure to these chemical compounds to risk leukemia at all exposure levels. WHO warns that any benzene exposure of $1 \mathrm{pg} / \mathrm{m}^{3}$ would have an additional 4 to 8 cases of leukemia per million population during life. ${ }^{6}$ The IARC stated that hematologic neoplasms such as myelogenous acute leukemia have been documented to occur at chronic exposure with low concentrations (10 ppm). ${ }^{5}$

\section{Safe Duration (Dt Safe)}

Safe Duration (Dt Safe) is safely associated with duration at work for a day and duration (in years) to work. It is important to set Dt safe in the workplace because it is related to safety. Determinants for safe duration involve good work rotation and ventilation in the workplace if working in a workplace that is chemically related. The formula used to calculate the safe $\mathrm{Dt}$ is:

Based on the calculation data in Table 3., it was known that the safe duration of worker respondents for work was 5.43 years. It means the worker in motor 
worksop area could work safely for 5.43 years depending on food intake and body condition respectively.

\section{CONCLUSION}

It was concluded that workers in the motor workshop area were at a risk of benzene exposure (noncarcinogenic) but could work safely for 5.43 years. It was depend on the food intake and the condition of each body of workers in the motor workshop environment. Recommendations were by consuming CYP2E1 enzyme contained in cow liver and salmon to lower benzene levels in the body. ${ }^{8}$

Conflict of Interest: All authors have no conflicts of interest to declare.

Source of Funding: This is an article "Determination of The Safe Duration of Benzene Non-Carcinogenic Exposure in Motor Workshop Area" of Occupational Health and Safety Department that was supported by Activity Budget Plans 2018, Faculty of Public Health, Airlangga University.

Ethical Clearance: The study was approved by the institutional Ethical Board of the Public Health, Airlangga University.

\section{REFERENCES}

1. ATSDR. Toxicological profile for benzena. US: U.S. Department of Health and Human Service; 2007.

2. Bae S, Pan XC, Kim SY, Park K, Kim YH, Kim $\mathrm{H}$, Hong YC. Exposures to particulate matter and polycyclic aromatic hydrocarbons and oxidative stress in school children. Environ Health Perspect. 2010; 118(4): p. 579-83.

3. Gammon MD, Santella RM. PAH, genetic susceptibility and breast cancer risk: an update from the long island breast cancer study project. Eur J Cancer. 2008; 44(5): p. 636-640.

4. Haen MT, Oginawati K. Hubungan pajanan senyawa benzena, tolena dan xylen dengan sistem hematologi pekerja di kawasan industri sepatu. Journal Teknik Sipil dan Lingkungan ITB. 2012; 8(7): p.1-4.
5. IARC. Diesel engine exhaust carcinogenic. In iarc monographs on the evaluation of carcinogenic risks to humans. International Agency for Research on Cancer Lyon, France; 2012. p. 105.

6. Larbey RI. Issues surrounding the use of lead in-economic and environmental. Science Total Environment. 1994; 19: p. 146-147.

7. Menteri Tenaga Kerja dan Transmigrasi RI. Permenakertrans No.13/MEN/X/2011 tentang nilai ambang batas faktor fisika dan faktor kimia di tempat kerja. Jakarta: Kementrian Tenaga Kerja dan Transmigrasi RI; 2011.

8. Nirmawati S, Tualeka AR, Adi AN. Effect of food containing high $\mathrm{Fe}$ (iron) intake to urinary trans, trans-muconic acid (Tt-ma) levels on workers exposed to benzene. Indian Journal of Public Health Research \& Development. 2018; 9(1): p. 53-57.

9. Reid BC, Ghazarian AA, DeMarini DM, Sapkota A, Jack D, Lan Q, Winn DM, Birnbaum LS. Research opportunities for cancer Associated with indoor air pollution from solid-fuel combustion. Environ Health Perspect. 2012; 120: p. 1495-1498.

10. Robbins, Kumar. Buku ajar patologi 1. Edisi 4. Jakarta: EGC; 1995. p. 290- 293.

11. Singh AK, Tomer N, Jain CL. Monitoring, assessment and status of benzene, toluene and xylene pollution in the urban atmosphere of Delhi, India. Res. J. Chem. Sci. 2012; 2(4): p. 45-49.

12. Tunsaringkarn T, Siriwong W, Rungsiyothin A, Nopparatbundit S. Occupational exposure of gasoline station workers to BTEX compounds in Bangkok, Thailand. The International Journal of Occupational and Environmental Medicine. 2012; 3(3): p. 117-25.

13. US-EPA. Benzene (CASRN 71-43-2). Washington, DC: Irish, US EPA; 2015.

14. White A, Teitelbaum SL, Stellman SD, Beyea J, Steck SE, Mordukhovich I, McCarty KM, Ahn J, Jr PR, Santella RM, Gammon MD. Indoor air pollution exposure from use of indoor stoves and fireplaces in association with breast cancer: A case-control study. Environ Health. 2014; 13 (108): p. 1-12. 